\title{
EMPHASIZING SOCIAL ISSUES TOWARD SUSTAINABLE SUPPLY CHAIN: A BRAZILIAN PERSPECTIVE
}

\author{
Minelle Enéas da Silva \\ Federal University of Rio Grande do Sul, Brazil \\ E-mail: minele-silva@hotmail.com \\ Luis Felipe Nascimento \\ Federal University of Rio Grande do Sul, Brazil \\ E-mail: nascimentolf@gmail.com \\ Submission: 02/01/2015 \\ Revision: 14/01/2015 \\ Accept: 23/01/2015
}

\section{ABSTRACT}

From sustainability perspective, the supply chain management strategy can use different indicators related to Triple Bottom Line to improve its practices. Some studies on the topic have focused only environmental issues; however in some cases the social issues should be considered as a core of the sustainable strategies. Considering this view, the paper aims to highlight the relevance of social issues in the Brazilian context toward sustainable supply chain. Therefore, a theoretical essay was conducted using the literature about sustainable supply chain in relation to the Brazilian perspective to understand how it is possible to use new approaches seeking an emphasis on social issues. The discussions indicate that to reconceptualize the social relations in supply chains, it's necessary to use corporate social responsibility and social capital approaches to create a better discussion about sustainable supply chain. This study starts a discussion in the Brazilian context to stimulate new scholars to research this topic.

Keywords: Sustainability; Supply Chain Management; Social Issues; Brazil; Corporate Social Responsibility; Social Capital. 
INDEPENDENT JOURNAL OF MANAGEMENT \& PRODUCTION (IJM\&P)

http://www.ijmp.jor.br

v. 6, n. 2, April - June 2015

ISSN: 2236-269X

DOI: 10.14807/ijmp.v6i2.288

\section{INTRODUCTION}

From discussion regarding new practices and behaviors in the society, studies emerged on sustainable development. This concept is understood as "a process of change in which the exploration of resources, the direction of investments, the orientation of technological development and institutional change are all in harmony" as well as indicates that human needs can be met now and in the future (WORLD COMMISSION ON ENVIRONMENT AND DEVELOPMENT [WCDE], 1987, p.43). This topic aims a harmony among three dimensions practiced by different social actors, namely: economic, environmental, and social (SACHS, 2007).

There are a lot of research trying to understand the sustainability dimensions, which can be focusing: urban sustainability, sustainable management, environmental sustainability, weak and strong sustainability, or just 'sustainability', even so we still have a great demand in relation to Triple Bottom Line as a whole (VALLENCE et al., 2011). However, as presented by Vallence et al. (2011) the scholars are presenting low concerns with organizational and operational aspects on social sustainability, for example. Thus, mostly talking about needs and aspirations in emerging economies it would be impossible to forget the social dimension of sustainability.

Considering this view, it is clear that business has a relevant contribution in new discussions and can influence directly for a transformation in relationships with other stakeholders. Therefore, Halldórsson et al. (2009, p.89) reflects in relation to current theoretical approaches and practices in supply chain management (SCM): "how can sustainability be integrated in the SCM approach? Is sustainability coherent, complementary or contradictory to the traditional SCM approach?" Actually we don't have responses, but it is noticeable that with new roles among different stakeholders the sustainable management can be easier.

Previous studies between environmental and organizational performance in developing countries have not been extensive (ZHU; SARKIS, 2007, p.4334), which present themselves even more limited in relation to social issues. Thus, this paper aims to highlight the relevance of social issues in the Brazilian context toward sustainable supply chain. The argument is based on the idea that the sustainability concept needs to be rethought in relation to the "local" level that can be inserted in the discussion as a whole. Up to here we consider the sustainable supply chain 
management (SSCM) as a main concept studied, but we can increase the discussion and try deepens the perspective when discussing emerging economies.

The sustainability perspective is being introduced in the research mainstream in supply chain management (BESKE; SEURING, 2014), but few studies consider an effective approach between the core of the themes (ASHBY et al., 2012; CARTER; ROGERS, 2008; CARTER; EASTON, 2011; SEURING; MÜLLER, 2008b). Thus, seeking to demonstrate the originality of our theoretical discussion, we understand that in some cases the social dimension should be considered as the core of the sustainable strategies, so that on a second stage the development of environmental strategies becomes possible, mostly related to some features of the context.

Therefore, methodologically, this study is a theoretical essay, because it is not restricted to analyzing what the literature shows, but is set up as a reflective writing that seeks to establish relationships and proposes discussions that enrich the debate about sustainable consumption (MENEGHETTI, 2011). To clarify the purpose, this paper is divided into four distinct parts. After this introduction, the next section presents the theoretical view about sustainability and SCM. In the third section, we indicate the discussion about the social issues in SSCM. After that, in the next sections, we bring some discussions and conclusions, showing the Brazilian perspective on the topic.

\section{SUSTAINABILITY AND SUPPLY CHAIN MANAGEMENT}

Debates on the changes around the world are being conducted over three decades and their agendas are always the relation between the human being and the environment in which mutual interaction is observed. In this new context, emerge the sustainable development that indicates to be necessary to search the transformation rather than maintaining the status quo (HOPWOOD et al., 2005). According to Schumacher (2001), based on the sustainable development model these changes can be aligned both to the reduction of goods productions and services, which generate a large environmental impact and a huge consumption rate in the society.

The Agenda 21 report (1992) shows different actions which stakeholders can use to make decisions in developing their activities. The business role in this context demonstrates that it is necessary to incorporate the Triple Bottom Line perspective among other things, with more relationships along its value chain focusing on the 
dynamic's market (ELKINGTON, 2002). For Peattie (2007), this idea can be corroborated because the businesses are within an economic and social system. Moreover, they need to direct their opportunities and practices according to a set of guidelines for sustainability. One opportunity in this way is the inter-organizational relationships.

There are many inter-organizational relationships, which can be highlighted: Alliances, Joint Ventures, Vertical Relationships, Franchising, Cross-sector Partnerships, and Networks (PARMIGIANI; RIVERA-SANTOS, 2011). Among these relationships, the focus for this paper is on the vertical relationship, specifically in the supply chain. According to Parmigiani and Rivera-Santos (2011), some traditional scholars indicate that an inter-organizational relationship facilitates achieving greater efficiency and valuable resources. From another perspective watching the partnerships that are created, it is emphasized that the activities are more effective and that the inter-organizational and interpersonal relationships are reinforced.

According to Burgess et al. (2006), there is little consensus on the supply chain concept, which is understood as a discipline that is still very fragmented (GIUNIPERO et al., 2008). It is assumed that the supply chain is "a set of three or more entities (organizations or individuals) directly involved in the upstream and downstream flows of products, services, finances and/or information from a source to a consumer" (MENTZER et al., 2001, p.4). With this perspective, a network of multiple businesses and relationships, the supply chain needs to be managed is understood, emerging the supply chain management (SCM) concept (CHEN; PAULRAJ, 2004; LAMBERT; COOPER, 2000). Thus, SCM is defined as:

The systemic, strategic coordination of the traditional business functions and the tactics across these business functions within a particular company and across businesses within the supply chain, for the purposes of improving the long-term performance of the individual companies and the supply chain as a whole (MENTZER et al., 2001, p.18).

For Burgess et al. (2006) this can be considered as a clearer definition for the topic. According to these authors, due to the lack of consistency in relation to the existing theoretical concept itself, one should seek to overcome the obstacle in relation to operations, which receives the greater focus on research on the topic, and try to adequate other views such as those related to strategic and organizational studies. In contrast, Giunipero et al. (2008) argue that the strategy issue got a jump 
research at the beginning of this century, thus requiring other insights. It is noteworthy that the term SCM is well established in theory, what is missing is greater consistency in its theoretical discussion (BURGESS et al., 2006).

At the current discussions on the relationship between supply chain and sustainability, the SSCM concept is more widespread. As presented by Ashby et al. (2012) the initial discussions under this perspective point out to the year 2003, but only in 2008 a wider range of articles was being published about the concept. This perspective is reaffirmed by Touboulic and Walker (2015) in its literature review. According to Carter and Easton (2011), this discussion has grown larger, because sustainability after becoming a big buzzword in the business world can be seen as a business license for the 21st century. Despite this purely economic and limited vision, it is not seen as the most widespread among the researchers of the subject.

In its literature review, Carter and Easton (2011) demonstrate that between 1991 and 2000 no item has been worked on sustainability; between 2001 and 2010 that he began to work with CSR (18.75\%); and between 2001 and 2010 only $25 \%$ of the articles analyzed properly used sustainability. This view was also presented by Carter and Rogers (2008) when they argue that most definitions of sustainability incorporates economic and environmental concerns as well as conceptualizations of CSR seeking to align social and environmental issues. From this view, in Table 1 are presented the main frameworks published to analyze the SSCM topic.

As can be seen in the Table we identify some existing frameworks, but have some weaknesses especially to understand which the main features that facilitate the better integration between sustainability and SCM are. The perspective emphasized in these frameworks considers sustainability as a moderator in the relations of the supply chain, leaving no clear contribution and better alignment between the topics. From this view, against the current configuration, it is understood that the discussion should create a deepen perspective, because the processes are rarely considered. Currently the most widespread concept on SSCM is:

[...] as the management of material, information and capital flows as well as cooperation among companies along the supply chain while taking goals from all three dimensions of sustainable development, i.e., economic, environmental and social, into account which are derived from customer and stakeholder requirements (SEURING; MÜLLER, 2008b, p. 1700). 
DOI: 10.14807/ijmp.v6i2.288

Table 1: Main frameworks on SSCM

\begin{tabular}{|l|l|}
\hline \multicolumn{1}{|c|}{ Authors } & \multicolumn{1}{|c|}{ Frameworks Outline } \\
\hline Carter and Rogers (2008) & $\begin{array}{l}\text { Have the dimensions of sustainability possible paths to follow, } \\
\text { however so widely that is not known at what time the } \\
\text { rapprochement between the themes can be practiced or even } \\
\text { encouraged in other chains that are not sustainable. }\end{array}$ \\
\hline Seuring and Müller (2008b) & $\begin{array}{l}\text { Demonstrate which the strategies to be implemented (1) management } \\
\text { of suppliers for risk assessment and performance, and (2) } \\
\text { management of the supply chain for sustainable products, however, } \\
\text { do not know what the limit relations among the subjects. }\end{array}$ \\
\hline Pagell and Wu (2009) & $\begin{array}{l}\text { It is highlighted as possible features for a more sustainable supply } \\
\text { chain: (1) existence of best practices, (2) re-conceptualization of the } \\
\text { entire chain, and (3) integration between chain links. Despite this } \\
\text { perspective, there seems to be a greater focus on discussion of the } \\
\text { environmental dimension of sustainability in the definition. }\end{array}$ \\
\hline Wolf (2011) & $\begin{array}{l}\text { Presents a possibility to observe as tangible the internal sustainable } \\
\text { aspects of focal firm and its interaction with the other participants in } \\
\text { the supply chain, a framework that is quite a direct and clear vision of } \\
\text { what can be studied. }\end{array}$ \\
\hline
\end{tabular}

Source: Own, based on Carter and Rogers (2008); Seuring and Müller (2008b); Pagell and Wu (2009); Wolf (2011).

As shown in the academic literature, other authors studying supply chain management has understood sustainability from the concept of the Triple Bottom Line (ASHBY et al., 2012; CARTER; ROGERS, 2008; FABBE-COSTES et al., 2011; GLOVER et al., 2014; PAGELL; WU, 2009; SEURING; MÜLLER, 2008a, 2008b), which searches through the appropriation of the idea of sustainable development to the business context, seeking a greater contribution from business for a change following the idea of shared collective value. Nevertheless, the issues are still not completing fully; it still needs deeper literature on the subject.

According to Ahi and Searcy (2013), at least twelve definitions can be observed in papers of SSCM. However, it is clear that there is some theoretical lack regarding how to integrate social and environmental sustainability in the context, since much has been on specific dimensions, primarily the environmental, but there are few papers with the integrated perspective, even suggesting the prospect of dealing with TBL (CARTER; EASTON, 2011; FABBE-COSTES et al., 2011; PAGELL; WU, 2009; SEURING; MÜLLER, 2008B; SVENSSON, 2007; WOLF, 2011). This is clear and receives greater emphasis mainly with regard to the social dimension, which is forgotten at the beginning of the discussions.

Focusing in this essay the social issues, we understand social sustainability as a set of 'human' elements geared towards total sustainability. Therefore, Vallence et 
al. (2011) propose as targeting approaches to study this dimension in relation to others: Development sustainability (addressing basic needs, the creation of social capital, justice and so on); Bridge sustainability (Concerning changes in behavior so as to achieve the bio-physical environmental goals); Sustainability and Maintenance (referring to the preservation, or what can be sustained, of socio-cultural characteristics in the face of change). The discussion considers even beyond the individual actions, but in the supply chain as a whole.

In the Brazilian context there are still few researches that assume the SSCM concept in its entirety (BRITO; BERARDI, 2010; CARVALHO; BARBIERI, 2013; GONÇALVES-DIAS et al., 2012; SILVA et al., 2013), seeking to create a national logic about the topic. These authors work with the perspective of the TBL as well as the interaction of different actors (multi-stakeholder) as influencing the structure of the supply chain. There are other authors who intend to study with the theme, but that make confusion between concepts and research in reverse logistics, environmental management and green supply chain management as synonyms of SSCM, which is not possible.

This perspective was evident in the research by Silva et al. (2013), which from a literature review in major Brazilian journals and conferences identified a limited number of articles that consider the matter at its completion. Moreover, according to these authors should be major concerns with translation and adjustments made, which can potentially affect the continuation of studies on the subject. Thus, Brazilian researches have not focused on supply chain and relationships as a whole, only on specific aspects of operations (BRITO; BERARDI, 2010; GONÇALVES-DIAS et al., 2012). Despite these limitations, it is clear that the issue has gradually been deepening in Brazil in order to understand the motivators for the inclusion of sustainable strategies along the supply chains.

\section{SUSTAINABLE SUPPLY CHAIN: AN EMPHASIS ON SOCIAL ISSUES}

For a better relationship between sustainability and supply chain management (SCM), Halldórsson et al. (2009, p.90) discuss the existence of three approaches: (1) an integrated strategy, where sustainability is consistent with SCM; (2) an alignment strategy, where sustainability is complementary to the traditional SCM, in relation to cost and services, and (3) a replacement strategy, where the traditional SCM concept 
is replaced by an alternative approach in relation to social and environmental aspects. According to these points of view, it is noticed that a great part of the research focuses on the second approach, and only a few on the first (Figure 1), and it was still not possible to observe the third.

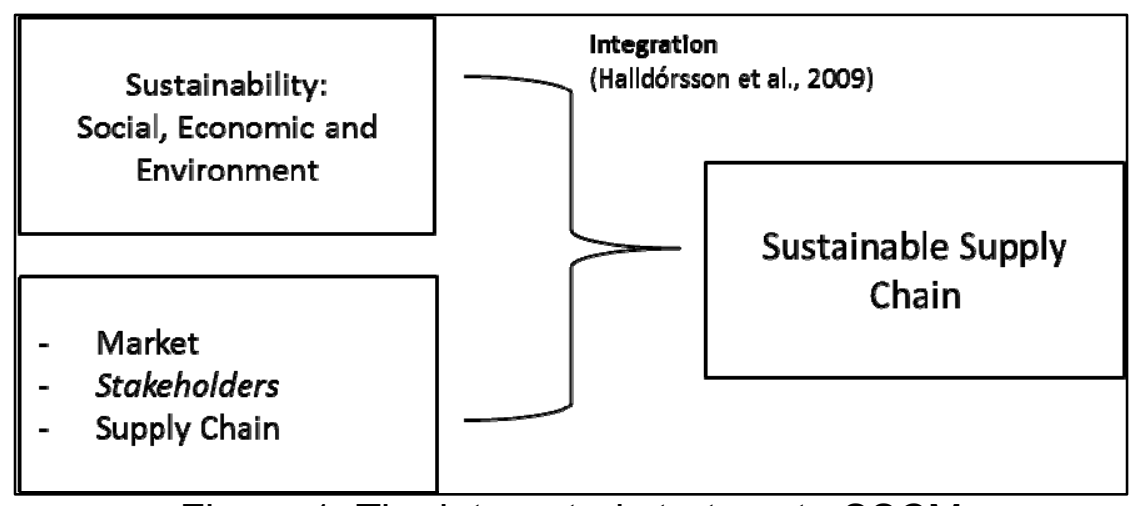

Figure 1: The integrated strategy to SSCM Source: Own, based on Halldórsson et al. (2009)

This proposal indicates that for better integration toward SSCM it is necessary to seek for a balance between the dimensions of sustainability, as well as closer ties with the strategy of supply chain is necessary. Therefore, as the social issues must be well studied, it gets highlighted. For a clearer discussion on the theoretical proposal, in relation to the study about SSCM, with a bigger focus on the social dimension of sustainability and its interaction with other dimensions, we did an overview on what has been published and discussed on the theme. There was not our focus a literature review, but it is necessary to know about social sustainability in relation to its integration with the supply chain management studies.

Among the many themes, we identified some aspects that can contribute to have equilibrium in the concept: Socially responsible purchasing (EHRGOTT et al., 2011; LEIRE; MONT, 2010); Social sustainability in supplier selection (CILIBERTI et al., 2008; EHRGOTT et al., 2011; HUTCHINS; SUTHERLAND, 2008); Social Life Cycle Analysis - SLCA (HUTCHINS; SUTHERLAND, 2008); Human rights (SHARMA; RUUD, 2003); Social reports (LEIRE; MONT, 2010) and; Corporate Social Responsibility - CSR (CILIBERTI et al., 2008). These are the main topics discussed in the literature. The majority of them have a focus in social issues only in the business, but it is clear that societal issues should to be practiced to have a great contribution for the sustainability. 
DOI: 10.14807/ijmp.v6i2.288

As can be seen in these themes, when social dimension of sustainability are discussed, few studies are focusing in sustainable supply chain. This occurs mostly because the focus has been on the changes of social practices and process in individual businesses. According to Leire and Mont (2010), social issues studied in this form have high internal legitimacy in organizations, which is related to routines and everyday decisions, though it is necessary to observe such questions in the supply chain as a whole. This occurs as discussed by Clift (2003), about sustainability, since what is internal in the organizations is not normally observed in all the supply chain. A tendency for corporate social responsibility is observed is these studies, which is not equivalent to sustainability concept.

When discussing corporate social responsibility (CSR), in order to encourage better alignment between sustainability and supply chain strategy, the main demand is related to suppliers (LEIRE; MONT, 2010). However, it is necessary to expand the impact of the social dimension and its interaction with other basic dimensions. As pointed out by Hutchins and Sutherland (2008), this is an issue that until recently has not been well defined. For these authors, the companies seek initially in their practices to remedy basic needs of employees and sometimes of community; however macro actions must also be considered. This idea differs from the sustainable practices in developing countries (MONT et al., 2010).

In the same way, Sharma and Ruud (2003) indicate that one should observe the aspect of social problems (with poverty reduction) and the minimization of environmental impacts, as in building networks and sustainable communities in developing countries, to consider the adequacy of country conditions, such as the set of small and medium enterprises (SMEs) that may be involved in the procurement process. Such a type of company needs a different view. For Ciliberti et al. (2008), from the perspective of CSR, this usually focuses on labor issues, considering the low labor costs and the perception that other countries have about the possibility of using this as an economic benefit for the business.

As an example, Ehrgott et al. (2011) research can be highlighted, on the social sustainability in suppliers' selection from a developed country perspective. As one seeks to change the interaction with another context, one should also modify their actions. According to the authors, the suppliers' selection was carried out in 
DOI: 10.14807/ijmp.v6i2.288

developing countries, leaving dubious understanding of the intentions of this process, if it has the approach of seeking to develop the best suppliers to provide a dynamic on sustainability in SCM, or if the idea is just reducing costs so in relation to what is known about the locality. The impacts of these practices are questionable, both in relation to the supply chain and for the development of the locality.

Other topic that can emerge as an emphasis on social issues, is dealing with the idea of social capital in the supply chain. According to Ketchen and Hult (2007), discussing social capital within a traditional view of supply chains is to seek to understand the conflicting loyalties between the company and the relationship. According to them, it is necessary to consider improved performance and the elaboration of common goals, values and experiences. For Min et al. (2008), the study of social capital is related to the discussion of social identity, which attempts to minimize loyalties that have conflicts among contexts.

With this view, we discuss a transposition of aspects that are individual to the business context as possible, seeking to consider other elements. According to Coleman (1988), capital can be understood as a resource available to facilitate the construction of a social structure conducive to the joint market proposed by Granovetter (1985). For Coleman (1988), social capital has a focus on individual contribution to the relationship between social actors. In other words it is directed for social relations. There are many definitions on this topic, whether internal or external to the organizations, but as Adler and Kwon (2002) present, there are a number of issues that confront these fields. For Putnam (1996), the ability of cooperation between groups and organizations is referred.

Under the supply chain perspective, one may consider the concept as a set of features that not only focuses on the relationship, but the interactions between the actors in such a relationship (MIN et al., 2008). This view however, brings much more of an economical than a social character, so when the idea of sustainability is discussed in the supply chain, one must deal with the social capital also as a resource, but one that can facilitate greater level of cooperation, collective action and strengthen relationships that encourage local development (ANDRADE et al., 2012). It is noteworthy that for the discussion made here, this development goes beyond the economic, influencing in the process of local change. 
Therefore, it is understood that there necessarily be an interaction of relationships and social structures considered with an institutionalization process of practices for sustainability, which can be well observed with respect to corporate social responsibility and the development of actions and practices that influence the community in different areas such as education, for example (CILIBERTI et al., 2008). Thus, according to Hutchins and Sutherland (2008), one should consider the identification of the borders surrounding social impact assessment resulting from the interaction between companies and their suppliers, among other actions. It would help if there was a narrowing between social relations, facilitating the sustainability.

There are different ways of dealing with this approach. For Ketchen and Hult (2007), this can be facilitated by the inclusion of discussions of organizational theories in the field of operations and supply chains. According to the authors, there are many discussions that may be performed even if the use of these theories is still at an early stage. For Gold et al. (2010), research that relate to organizational theories can contribute to a better understanding of inter-organizational processes. Thus, the Institutional Theory (IT) stands out. According to Zsidisin et al. (2005), institutional theory emphasizes the idea of homogeneity, which considers both the focus of internal and contextual practices, encouraging a convergence between the intra- and inter-organizational practices.

Some papers are published approaching institutional theory in discussions of sustainability and SCM; however mainly focused in the environmental dimension of sustainability (GROB; BENN, 2014; GLOVER et al., 2014; SARKIS et al., 2011; ZHU; SARKIS, 2007). According to Moxham and Kauppi (2014), using IT is possible to achieve the social issues in sustainable supply chain. For them, the way for that can be to use the fair trade perspective seeking to legitimate the use of social dimension in the topic. In relation to social issues, it is also possible to apply institutional theory to study CSR and Social Capital. From the discussion conducted, it is clear that the social issues can be the core of the strategies and contribute directly for sustainable supply chain in different perspective. Next section highlights the Brazilian context.

\section{DISCUSSION}

As presented in our arguments until here, the social issues can be considered a strategic pillar toward sustainable supply chain. This is a necessity around world, 
but mostly in emerging economic, since the social issues require more attention in the society. We bring the Brazilian perspective to discuss about a demand that is clear in our daily operations, but this debate is also necessary considering the last cases of slave labor that some company are presenting. Moreover, child labor and lack of human right are latent aspects that are observed as result of a low concern of companies in their practices and in certificate or auditee its suppliers.

Therefore, Griesse (2007) argues that the Brazil is considered as a multifaceted country, in which it should consider to create a better set of interactions between organizations in the market: the geographical diversity, inequalities in socioeconomic issues, and current trends in policy and economy, which tend to adjust to the practices that are developed in the supply chains depending on the characteristics that surround them. From this reflection, it is necessary to thought about an inquiry conducted by Sharma and Ruud (2003), would sustainability in supply chains be conditioned to groups or networks of organizations in the same geographic region, therefore fragmenting the global chains?

Considering this point of view, as shown by Griesse (2007), among other aspects geographical diversity has great influence on the process of building strategies. In order to do this, we need to re-conceptualize the chain as a whole, bringing other actors to the new integration (PAGELL; WU, 2009). This different logic was presented by the idea of social capital, which is related to different social relations in society. According to our arguments, if more social issues are introduced in the company strategy (i.e. corporate social responsibility and social capital), a sustainable supply chain emerges as possible.

According to Gonçalves-Dias et al. (2012, p.529) "it is necessary to emphasize the reality of the country, to highlight genuine Brazilian innovations, [...] and on practical initiatives not yet systematized by the academy". This perspective opens a research field which can demonstrate, from a critical point of view, their own point of view coming from their specificities. Thus, it is clear that the current setting on the topic is interesting in the sense of being stimulated by research throughout the world, but there are many advances needed on the global research agenda. Moreover, a new agenda should to emerge in the Brazilian context since to demonstrate that the social issues are an important topic to contribute for the sustainability. 
DOI: $10.14807 /$ ijmp.v6i2.288

\section{CONCLUDING REMARKS}

The challenge is to advance the sustainable supply chain concept and consider the social aspects towards the central condition in a more sustainable management, mostly in emerging economies. This is important in these economies, mainly because different necessities emerge as relevant toward to a transformation for sustainability. Considering this perspective, this view creates a logic of greater integration between the dimensions of sustainability, being that if the social is highlighted by local needs, this creates a direct influence on the environment and consequently in the dynamic business of the country.

We should rethink what is the supply chain, whether it is a linear sequence of boxes that influence in a certain way, or the relationship between a set of actors that interact, relate and meet a desired collective goal. Using the idea of alternative ways of looking at this social structure, demonstrates the possibility of new features. Therefore, we can also rethink the role received for the sustainability incorporated into organizations. Its discussion goes beyond the competitive advantage and concern to the environment; it is assumed a change in values. Thus, emerge the following propositions in this context:

- Proposition 1: In order to stimulate a more sustainable supply chain in the Brazilian context, the CSR and social capital approaches should to be inserted in the company strategies;

- Proposition 2: Considering Brazil as a multifaceted country and with latent cases involving negative aspects in this theme, Brazilian studies can focus more on social issues to understand SSCM;

- Proposition 3: To create a research field in sustainable supply chain in Brazil, scholars need to introduce more social aspects to analyze companies and develop studies on the topic.

From these discussions, it is clear that it is possible that from the empirical phase new aspects can be raised and different contributions will be introduced to adapt the concept to the context of the locality. For instance, to identify what is the topic studied in relation to the proposal and bring new inputs in both theoretical perspective and practical implications. Therefore, the main contribution of this 
DOI: 10.14807/ijmp.v6i2.288

theoretical discussion it is the social as an emergent topic in studies on sustainable supply chain, mostly in emerging economies including Brazil; and identifies that the social issues (i.e. CSR and Social Capital) should be approximated of sustainability discussions in the supply chain strategy.

\section{REFERENCES}

ADLER, P. S.; KWON, S-W. (2002). Social Capital: Prospects for a new concept, Academy of Management, v. 27, n. 1, p. 17-40.

AGENDA 21. (1992). United Nations Conference on Environment \& Development,

https://sustainabledevelopment.un.org/content/documents/Agenda21.pdf, Accessed: February 2014

AHI, P.; SEARCY, C. (2013). A comparative literature analysis of definitions for green and sustainable supply chain management, Journal of Cleaner Production, n. 52.

ANDRADE, E. O.; GOMES, F. S. L.; CÂNDIDO, G. A. (2012). Capital Social como mecanismo para melhorias nas formas de atuação de cooperativas de produtores rurais, Revista Brasileira de Gestão e Desenvolvimento Regional, v. 8, n. 2.

ASHBY, A.; LEAT, M.; HUDSON-SMITH, M. (2012). Making connections: a review of supply chain management and sustainability literature, Supply Chain Management: An International Journal, v. 17, n. 5, p. 497-516.

BESKE, P.; SEURING, S. (2014). Putting sustainability into supply chain management, Supply Chain Management: an international journal, v. 19, n. 3.

BRITO, R. P.; BERARDI, P. C. (2010). Vantagem Competitiva na Gestão Sustentável da Cadeia de Suprimentos: um metaestudo. Revista de Administração Eletrônica - RAE, v. 50, n. 2, p. 155-169, abr./jun.

BURGESS, K.; SINGH, P. J.; KOROGLU, R. (2006). Supply chain management: a structured literature review and implications for future research, International Journal of Operations \& Production Management, v. 26, n. 7, p. 703-729.

CARTER, C. R.; EASTON, P. L. (2011). Sustainable supply chain management: evolution and future directions. International Journal of Physical Distribution \& Logistics Management, v. 41, n. 1, p. 46-62.

CARTER, C. R.; ROGERS, D. S. (2008). A framework of sustainable supply chain management: moving toward new theory. International Journal of Physical Distribution \& Logistics Management. v. 38, n. 5, p. 360-387.

CARVALHO, A. P.; BARBIERI, J. C. (2013). Inovações Socioambientais em cadeias de suprimentos: um estudo de caso sobre o papel da empresa focal, RAI - Revista de Administração e Inovação, v. 10, n. 1, p. 232-256.

CHEN, I. J.; PAULRAJ, A. (2004). Towards a theory of supply chain management: the constructs and measurements, Journal of Operation Management, n. 22, p. 119-150. 
CILIBERTI, F.; PONTRANDOLFO, P.; SCOZZI, B. (2008). Investigating corporate social responsibility in supply chains: a SME perspective, Journal of Cleaner Production.

CLIFT, R. (2003). Metrics for supply chain sustainability, Clean Technology Environmental Policy, v. 5, p. 240-247. 2003.

COLEMAN, J. S. (1988). Social Capital in the creation of human capital, American Journal of Sociology, n. 94, p. 95-120.

EHRGOTT, M.; REIMANN, F.; KAUFMANN, L.; CARTER, C. R. (2011). Social sustainability in selecting emerging economy suppliers, Journal of Business Ethics, n. 98, p. 99-119.

ELKINGTON, J. (2002). Cannibals with forks: the triple bottom line of 21st century business [reprint]. Oxford: Capstone.

FABBE-COSTES, N.; ROUSSAT, C.; COLIN, J. (2011). Future sustainable supply chains: what should companies scan? International Journal of Physical

Distribution \& Logistics Management, v. 41, n. 3, p. 228-252.

GIUNIPERO, L. C.; HOOKER, R. E.; JOSEPH-MATTHEWS, S.; YOON, T. E.; BRUDVIG, S. (2008). A decade of SCM literature: past, present and future implications, Journal of Supply Chain Management, v. 44, n. 4, p. 66-86.

GLOVER, J. L.; CHAMPION, D.; DANIELS, K. J.; DAINTY, A. J. (2014). An Institutional Theory perspective on sustainable practices across the dairy supply chain, International Journal of Production Economics, n. 152, p. 102-111.

GOLD, S.; SEURING, S.; BESKE, P. (2010). Sustainable Supply Chain Management and Inter-Organizational Resources: a Literature Review. Corporate Social Responsibility and Environmental Management, v. 17, n. 4, p. 230-245.

GONÇALVES-DIAS, S. L. F.; LABEGALINI, L.; CSILLAG, J. M. (2012).

Sustentabilidade e cadeia de suprimentos: uma perspectiva comparada de publicações nacionais e internacionais, Produção, v. 22, n. 3, p. 517-533.

GRANOVETTER, M. (1985). Economic Action and Social Structure: the problem of embeddedness, The American Journal of Sociology, v. 91, n. 3, p. 481-510.

GRIESSE, M. A. (2007). The geographic, political, and economic context for Corporate Social Responsibility in Brazil, Journal of Business Ethics, n. 73, p. 2137.

GROB, S.; BENN, S. (2014). Conceptualising the adoption of sustainable procurement: an institutional theory perspective, Autralasian Journal of Environmental Management, v. 21, n. 1, p. 11-21.

HALLDÓRSSON, Á.; KOTZAB, H.; SKJOTT-LARSEN, T. (2009) Supply chain management on the crossroad to sustainability: a blessing or a curse? Logistics Research, p. 83-94.

HOPWOOD, B.; MELLOR, M.; O’BRIEN, G. (2005). Sustainable Development: Mapping Different Approaches, Sustainable Development, n. 13, pp. 38-52.

HUTCHINS, M. J.; SUTHERLAND, J. W. (2008). An exploration of measures of social sustainability and their application to supply chain decisions, Journal of Cleaner Production, p. 1688-1698. 
KETCHEN JR., D. J.; HULT, G. T. M. (2007). Bridging organization theory and supply chain management: the case of best value supply chains, Journal of Operations Management, n. 25, p. 573-580.

LAMBERT, D. M.; COOPER, M. C. (2000). Issues in Supply Chain Management, Industrial Marketing Management, n. 29, p. 65-83. 2000.

LEIRE, C.; MONT, O. (2010) The implementation of Socially Responsible Purchasing, Corporate Social Responsibility and Environmental Management, $\mathrm{n}$. 17, p. 27-39.

MENEGHETTI, F. K. (2011). O que é um ensaio teórico? Revista de Administração Contemporânea - RAC, v. 15, n. 2, p. 320-332.

MENTZER, J.T.; DEWITT, W.; KEEBLER, J. S.; MIN, S.; NIX, N. W.; SMITH, C. D.; ZACHARIA, Z. G. (2001). Defining Supply Chain Management, Journal of Business Logistics, v. 22, n. 2, p. 1-25.

MIN, S.; KIM, S. K.; CHEN, H. (2008). Developing social identity and social capital for supply chain management, Journal of Business Logistics, v. 29, n. 1.

MONT, O.; KOOG, B.; LEIRE, C. (2010). Sustainable businesses practices in supply chains: experiences from Swedish companies. Presented in: The $14^{\text {th }}$ European Roundtable on Sustainable Production and Consumption (ERSPC) and The $6^{\text {th }}$ Environmental Management for Sustainable Universities (EMSU), ERSPCEMSU conference. The Netherland. 2010.

MOXHAM, C.; KAUPPI, K. (2014). Using organizational theories to further our understanding of socially sustainable supply chains: the case of fair trade, Supply Chain Management: an International Journal, v. 19, n. 4, p. 413-420.

PAGELL, M.; WU, Z. (2009). Building a More Complete Theory of Sustainable Supply Chain Management Using Case Studies of 10 Exemplars. Journal of Supply Chain Management.

PARMIGIANI, A.; RIVERA-SANTOS, M. (2011). Clearing a path through the forest: a meta-review of inter-organizational relationships, Journal of Management, v. 37, n. 4.

PEATTIE, K. (2007). Toward sustainable organizations for the 21st century. 21st Century Management: A Reference Handbook. SAGE Publications.

PUTNAM, R. D. (1996). Comunidade e Democracia: a experiência da Itália Moderna. Rio de Janeiro: FGV.

SACHS, I. (2007). Rumo à ecossocioeconomia: Teoria e prática do desenvolvimento. São Paulo: Cortez.

SARKIS, J.; ZHU, Q.; LAI, K-H. (2011). An organizational theoretic review of green supply chain management literature, International Journal of Production

Economics, p. 1-15.

SCHUMACHER, E. F. (2001). Lo pequeño es hermoso. 3ed. España: Tursen S.A.

SEURING, S.; MÜLLER, M. (2008a). Core issues in Sustainable Supply Management - a Delphi study, Business Strategy and the Environment, n. 17, p. 455-466. 
SEURING, S.; MÜLLER, M. (2008b). From a literature review to a conceptual framework for sustainable supply chain management. Journal of Cleaner Production, n. 16, p. 1699-1710.

SHARMA, S.; RUUD, A. (2003). On the path to sustainability: Integrating social dimensions into the research and practice of environmental management, Business Strategy and the Environment, Editorial, n. 12, p. 205-214.

SILVA, M. E.; NEUTZLING, D. M.; ALVES, A. P. F.; DIAS, P.; SANTOS, C. A. F.; NASCIMENTO, L. F. M. (2013). Gestão da Cadeia de Suprimentos Sustentável: entendendo o discurso brasileiro. Presented in: XXXVII Encontro da ANPAD. Rio de Janeiro: RJ, Brazil.

SVENSSON, G. (2007). Aspects of sustainable supply chain management (SSCM): conceptual framework and empirical example, Supply Chain Management: An International Journal, v. 12, n. 4, p. 262-266.

TOUBOULIC, A.; WALKER, H. (2015). Theories in sustainable supply chain management: a structured literature review, International Journal of Physical Distribution \& Logistics Management, v. 45, n. $1 / 2$. http://dx.doi.org/10.1108/IJPDLM-05-2013-0106.

VALLANCE, S.; PERKINS, H. C.; DIXON, J. E. (2011). What is social sustainability? A clarification of concepts, Geoforum, n. 42, p. 342-348.

WORLD COMMISSION ON ENVIRONMENT AND DEVELOPMENT (WCED). (1987). Report Our common future, http://www.un-documents.net/wced-ocf.htm, Accessed: May 2013.

WOLF, J. (2011). Sustainable Supply Chain Management Integration: A Qualitative Analysis of the German Manufacturing Industry, Journal of Business Ethics, v. 102, p. 221-235.

ZHU, Q.; SARKIS, J. (2007). The moderating effects of institutional pressures on emergent green supply chain practices and performance, International Journal of Production Research, v. 45, n. 18/19, p. 4333-4355.

ZSIDISIN, G. A.; MELNYK, S. A.; RAGATZ, G. L. (2005). An institutional theory perspective of business continuity planning for purchasing and supply management, International Journal of Production Research, v. 43, n. 16. 